\title{
Utazás előtti tanácsadás - fogorvosi szempontból
}

\author{
DR. FELKAI PÉTER*, DR. FELKAI TAMÁS**, DR. RÓZSA NOÉMI**
}

\begin{abstract}
Az utazás alatti egészségkárosodások 3,5-7,8\%-a fogászati jellegű, tehát egyrészt jelentős nagyságrendű problémakörről van szó, másrészt a külföldi fogorvosi kezelés drága és nem minden utazási biztosítás fedezi azt teljes egészében. Ezért az utazás előtti tanácsadásnak tartalmaznia kell a fogászati jellegű bajok ismertetését, megoldási módjait. Fontos szempont a szájhigiénia hangsúlyozása (biztonságos fog- és protézismosó vízzel), a protézisek és a fogszabályozó készülékekkel kapcsolatos tennivalók ismertetése. A nem megbízható külföldi szolgáltató kezelése súlyos fertőzést, esetenként HIV fertőzést is eredményezhet.

Fontos tudnivaló hogy az egyes fogorvosi kezelések után mikor repülhet az utazó: Általánosságban elmondhatjuk, hogy a barodontalgia veszélye miatt fogtömések után 24 órát, gyökérkezelés után 72 órát, szövődménymentes implantáció után 24-48 órát, nagyobb orofaciális beavatkozások után (többszörös implantáció, csontpótlás stb.) után két hetet ajánlatos várni a légi utazással. Természeten a várakozási idő függ a beteg mindenkori állapotától és az elvégzett beavatkozás nagyságától is.
\end{abstract}

Kulcsszavak: utazási tanácsadás, barodontalgia, fogorvosi tanácsadás, repülés, szájhigiénia

\section{Bevezetés}

Az utazás előtti tanácsadás hazánkban még gyerekcipőben jár: az utazók többsége csak a védőoltások felvétele céljából keresi fel az oltóközpontokat, az utazással kapcsolatos egészségi kérdésekben - ha egyáltalán - az alapellátás orvosait: a háziorvost vagy a foglalkozás-egészségügy orvosát keresi meg. Az utazási tanácsadás általában a desztináció országaiban meglévő endémiás betegségek és veszélyes tényezők ismertetésén kívül az utazó krónikus betegségeivel kapcsolatos kérdések megválaszolásából áll. Legtöbbször elmarad a lehetséges fogászati bajok felléptével kapcsolatos tanácsadás, noha a lakosság egyre nagyobb hányada fogászati gonddal küszködik [1]. Ezért nem árt, ha ezeket, az utazással kapcsolatos elővigyázatossági intézkedéseket a fogorvos is ismerteti betegeivel.

Ha figyelembe vesszük, hogy az utazóknak milyen alacsony százaléka veszi igénybe az utazás előtti orvosi tanácsadást, az utazás előtti fogorvosi vizsgálatról még inkább aggasztó képet kaphatunk. Pedig a fogorvosi megbetegedésekkel kapcsolatos panaszok az utazók 3,5-7,2\%-át [2, 3] érintik, tehát jelentős kérdésről van szó. Azonban az alapellátás orvosainak és a fogorvosoknak egyaránt kevés idevágó szakmai útmutatás áll rendelkezésre, ezért szükségesnek látszik, hogy a hazai és nemzetközi közlemények alapján összefoglaljuk az utazásorvostani diszciplína ide vonatkozó javaslatait.

\section{Utazással összefüggő fogászati problémák}

\section{Fertőző betegségek átvitele}

a külföldön végzett

fogorvosi beavatkozások alkalmával

A külföldi utazás alkalmával a hirtelen fellépő fogászati megbetegedés az egyik legijesztőbb kórkép az utazó számára: megbízható fogorvosi ellátást egy ismeretlen országban nehéz találni, ráadásul az ellátás igen drága és nem minden utazási biztosítás fedezi a fogorvosi ellátást. A fejlődő országokban a nem megfelelő vagy nem létező sterilizáció eljárások miatt fennáll a hematogén úton megkapott fertőzések veszélye. Előfordulhat az is, hogy a beteg a kezelő orvostól kapja el $[4,5]$ az AIDS és a hepatitis fertőzést. Mivel a beteg ritkán tudja ellenőrizni a megfelelő sterilizálás meglétét, ennek a veszélynek az elkerülésére a tanácsadáskor a drágább (de valószínúleg jobban felszerelt) orvosi rendelők felkeresését és a megfelelő, fogorvosi ellátást is magában foglaló utasbiztosítás megkötését javasoljuk.

\section{Barodontalgiák}

A légiutazás alkalmával fellépő a „repülők fogfájásának” nevezett jelenség a légnyomásváltozás okozta barodontalgia. Elsőként a II. világháború pilótái számoltak be róla, mert ők már 10000 méteres magasságban is repültek - ekkor még nem nyomáskiegyenlített kabinban. Érdekes módon ma is ez a leggyakoribb egészségi panasz a vadászrepülők között [6]. Sajnálatos 
módon azonban még a Nemzetközi Légi Szállítási Szövetség (IATA) orvosi szabálykönyve sem említi sem a fogbetegségek, sem a barodontalgia által okozott fájdalmat és annak megelőzését, noha annak gyakorisága $0,26 \%$ a légiutasok között [7].

Az utaskabinban ugyanis a 10000 méteres utazómagasság eléréséig fokozatosan csökkentik a légnyomást annak érdekében, hogy kevésbé feszítse szét a repülögép falát a külső alacsony légnyomás. Az utaskabinban a lecsökkentett légnyomás megfelel a 2500 méteres földi nyomásnak megfelelő értéknek (ezt nevezik kabinnyomásnak). A középfülben lévő tengerszinti nyomás a repülő felszállása közben kitágul (,pattog a fülünk”), de a nyomás az Eustach-kürtön keresztül kiegyenlítődik, illetve nyeldekeléssel (mely megfelel a Valsalva manővernek) kiegyenlítjük. Mivel a gáz nyomásának és térfogatának aránya állandó (Boyle-Mariotte gáztörvény), leszálláskor fordított folyamat zajlik le. A testüregekben lévő tengerszinti nyomás és a kabinnyomás, ha nincs akadálya (például katarrheás, ödémás légutak, zárt testüregek) hamar kiegyenlítődik.

A testüregekbe zárt (sinusok vagy hasüreget megnyitó mútét) vagy a fogtömés alá szorult levegő azonban nem tud kiegyenlítódni és feszítő fájdalmat, legrosszabb esetben barotraumát ( $p l$. a dobhártya szakadását) okozva. A gingiva abszcessusa például emelkedéskor okoz fájdalmat [8]. Egy kimutatás szerint [6] a leggyakoribb barodontalgiát okozó tényező a pulpitisz $(40,7 \%)$, amely caries vagy egyéb fogászati kezelés következménye: ez éles fájdalmat okoz emelkedéskor vagy ereszkedéskor. A dentoalveoláris, apicalis tályog (18,5\%) emelkedéskor okoz fájdalmat, a sinusitisek és a carieses fog $(18,5 \%)$ emelkedéskor és ereszkedéskor okoznak barodontalgiát (1. ábra).

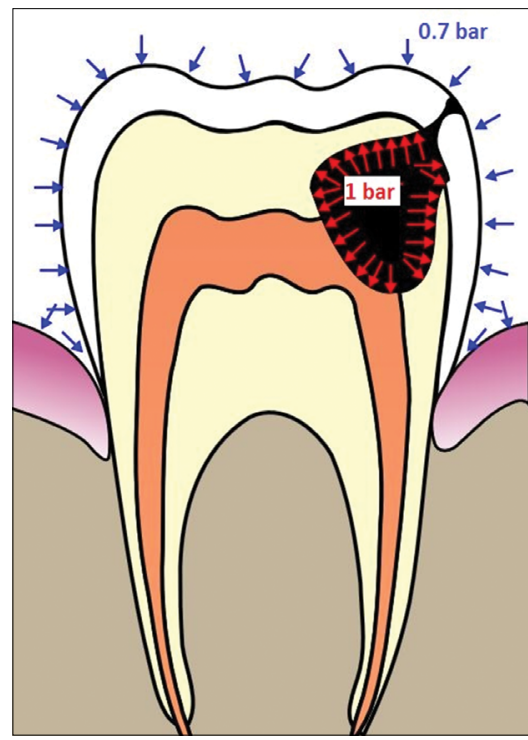

1. ábra: A caries üregében lévő

tengerszinti nyomás $(760 \mathrm{Hgmm}=1$ bar) feszíti az üreg falát a kabinnyomás alacsonyabb volta $(523 \mathrm{Hgmm}=0,7 \mathrm{bar})$ miatt.

Egy másik felmérés szerint [9] barodontalgiát 29,2\%ban okozott a rosszul kivitelezett fogtömés. A fájdalomért 27,8\%-ban az apicalisan elhelyezkedő periodontitis, illetve a nekrotizált pulpa; 13,9\%-ban pedig a nem megfelelő gyökérkezelés volt a felelős.

A barodontalgia klasszifikációját a kompressziódekompresszió tükrében négy osztályba sorolják [10], és ezt az osztályozást a World Dental Federation is elfogadta [11] (1. táblázat).

Barodontalgia azonban nem csak a repülőgépen utazónak fájdalmas tapasztalat, de a búvároknál is fellép,

A barodontalgia klasszifikációja és tünettana

\begin{tabular}{|l|l|l|}
\hline Osztályozás & A barodontalgia oka & Tünetek \\
\hline I. osztály & Irreverzibilis pulpitis & Felszálláskor éles fájdalom \\
\hline II. osztály & Reverzibilis pulpitis & Tompa fájdalom felszálláskor/emelkedéskor \\
\hline III. osztály & Necrotizált pulpa & Ereszkedéskor/leszálláskor tompa fájdalom \\
\hline IV. osztály & $\begin{array}{l}\text { Periapicalis pathológiás történések } \\
\text { (periodontitis, cysta stb.) }\end{array}$ & Éles, állandó fájdalom emelkedéskor és ereszkedéskor \\
\hline
\end{tabular}

Ajánlott várakozási idők egyes fogorvosi beavatkozások után

\begin{tabular}{|l|l|}
\hline Beavatkozás & Repülés/búvárkodás legkorábban \\
\hline fogtömés & 24 óra múlva, repülőszemélyzetnél is [14] \\
\hline foghúzás & általában 24 óra múlva, repülőszemélyzetnél 24-72 óra [15] \\
\hline implantáció, szövődménymentes & $24-48$ óra múlva (általában a pilóták és a repülőszemélyzet már másnap repülni szokott) \\
\hline implantáció, kisebb szövődménnyel & $48-72$ óra [16] \\
\hline többszörös implantáció & 2 hét, esetleg szövődménymentesen 10 nap [17] \\
\hline gyökérkezelés & min. 72 óra, de egy hét várakozás biztonságosabb \\
\hline $\begin{array}{l}\text { Bonyolultabb orofaciális beavatkozás } \\
\text { (pl. arcüreg emelés stb.) }\end{array}$ & min. 2 hét \\
\hline
\end{tabular}


ugyanolyan arányban (11,9\%), mint a szuperszónikus vadászgépet vezető pilótáknál (11\%), tehát a tengerparti sportra indulóknak adott tanács során érdemes erre is kitérni [12]. Sőt, a havas sportokra indulóknak is meg kell említeni a magasság okozta barodontalgiát: egy reprezentatív felmérés szerint a síelők 13\%-a (!) érzett fájdalmat, sokuk 1 óránál tovább is fájdalmat panaszolt [13].

Sajnálatos módon csak kevés irodalmi adat utal a különböző fogorvosi beavatkozások utáni légi utazás legkorábbi időpontjára. Nyilvánvalóan minden beteg egyéni megítélést igényel, de általánosságban a következő időtartamok betartását ajánljuk, különböző fogorvosok és repülőszemélyzetek tapasztalatai alapján (2. táblázat).

Ha mégis feltétlenül a repülőutat kell választani a fogorvosi beavatkozások után, a levegőben kezdődő fogfájást jegeléssel lehet enyhíteni, a repülés előtti órában pedig NSAID, illetve fájdalomcsillapító prevenciós szedésével lehet próbálkozni.

\section{A meglévő fogpótlással összefüggő gondok}

A külföldi utazással kapcsolatos fogorvosi azonnali beavatkozást igénylő betegségek egy felmérés szerint roszszul kivitelezett tömés (36\%), pulpitisz (20\%), protézistörés és caries (mindkettő 11,5\%) volt [2].

A külföldi utazás alatt megfelelő fogorvosi ellátót találni nehéz és költséges feladat. Mivel az utazási biztosítások legtöbbje csak az akut problémák megoldását fedezi, néhány előrelátó tanáccsal megkönnyíthetjük az utazó dolgát. A kivehető fogsorral rendelkező utazónak tanácsos tartalék fogsort magával vinni, mert egy lemezes fogpótlás törésének a javítása gond lehet külföldön. A megfelelő tisztító- és rögzítőszerek megléte az utazó érdeke. Előfordulhat, hogy a nem megfelelő higiéniás körülmények miatt a kivehető rész alatt gyulladásos elváltozások keletkeznek, vagy decubitusok jelennek meg.

A fogszabályozó készülékek javítását jobb, ha ortodontus szakorvos végzi. A sérült kivehető készüléket ne használja az utazó, amíg a javítást el nem végzik, mert a törött részek a szájban sérüléseket, esetleg aspirációt okozhatnak. A rögzített készülékeknél is jobb, ha csak a közvetlen hiba elhárítására szorítkoznak (laza bracket, kiálló drótív, ligatúra eltávolítása), mert az ilyen kezelések sokfélesége nem biztosítja a szakszerü helyreállítást. A sínes kezeléseknél ilyen gondok általában nem jelentkeznek.

A beragasztott hidak kozmetikai leplezésének ( $\mathrm{pl}$. a fémvázról leváló porcelán) esztétikai kérdése, megoldása későbbre halasztható. A hídváz törése esetén, ha a nyálkahártyán komolyabb sérülést okoz, fogorvoshoz kell fordulni. De a porcelánleplezés éles törési felülete, vagy a hídváz törése esetén, ha az a nyálkahártyát irritálja, szintén fogorvoshoz kell fordulni. Önkezű javításnak nincs helye, mert a laikus által reparált híd a szóló pillér-fog parodontalis károsodásához vezethet. Az implantációs fogpótlások esetében javasolt az utazás előtti fogorvosi ellenőrzés.

\section{Szájüregi higiénés megfontolások utazás alatt}

Noha az utazók többsége tudja, hogy a legtöbb országban - föleg a trópusi, szubtrópusi övezetekben - a csapvíz fogyasztása veszélyes a vizek szennyezettsége miatt, mégis előfordul, hogy a biztonságos ital fogalmát leszúkítik a palackozott ivóvíz fogalmára, és nem gondolnak arra, hogy fogmosásra, a protézis tisztítására is palackozott vizet kell használni. Ezért erre mindenképpen hívjuk fel az utazó figyelmét a tanácsadás alkalmával.

A carieses foggal utazót a környezet változása, az ételek különbözősége miatt könnyen érheti fog eredetü akut gyulladásos folyamat, vagy egy korábbi gyulladásos folyamat fellángolása. A tüneti fájdalomcsillapítás, öngyógyítás sokszor nem vezet eredményre, ezért az utazás előtt az utazó itthoni fogorvosának felkeresése igen ajánlatos [18]. Mindezek a megfontolások az utazó gyermekre is vonatkoznak, de a középkorú és idős nemzedéknél - értelemszerúen - még fontosabbak.

\section{Fogorvosi rendelök külföldön}

A krónikus fogbetegséggel vagy a fogpótlás különböző módjaival kezelt betegeknek szüksége lehet külföldön hirtelen fogorvosi kezelésre. Ezek megtalálása - fejlett országokban - nem jelent gondot, de más régiókban gondosan meg kell válogatni az ellátókat, hiszen a beteg nem tudhatja, hogy milyen színvonalú ellátót tanácsol neki a helyi idegenvezető vagy a szállodai recepciós (sokszor ezek a nekik legtöbb jutalékot fizető ellátót ajánlják). Az eszközök megfelelő sterilizálása, az egyszer használatos eszközök használata az infekciókontroll szempontjából életfontosságú tényezők. Sokkal biztosabb az adott ország követségét megkérdezni, vagy hiteles honlapon (pl. a Nemzetközi Utazásorvostani Társaság - International Society of Travel Medicine) kell ellátót keresni.

Mivel a fogorvosi ellátás külföldön igen költséges, ezért nem árt megfelelő biztosítást kötni - és annak megvásárlása előtt ellenőrizni, hogy a költségek fedezése milyen fogorvosi tevékenységre terjed ki, mert ez biztosítónként és biztosítási módozatokként is változik.

\section{Irodalom}

1. Madléna M, Hermann $P$, Jáhn $M$, Fejérdy $P$ : Caries prevalence and tooth loss in Hungarian adult population: results of a national survey BMC Public Health 2008; 8, 364. https://doi.org/10.1186/14712458-8-364

2. Soвotta BAJ, John MT, Nitschke I: Cruise Medicine: The Dental Perspective on Health Care for Passengers During a World Cruise Journal of Travel Medicine 2008; 15, 1, 19-24. https://doi. org/10.1111/j.1708-8305.2007.00162.x

3. Leggat PA, Leggat FW, Kedjarune U: Travel insurance claims made by travellers from Australia for dental conditions. Int Dent $J$ 2001; 51, 268-272. https://doi.org/10.1002/j.1875-595X.2001. tb00836.x

4. Florence E, Gompel van A, Colebunders: Dental Precautions for Travelers Journal of Travel Medicine 1997; 4, 1, 38-44. https:// doi.org/10.1111/j.1708-8305.1997.tb00771.x

5. Kane MA, Lettau LA. Transmission of HBV from dental personnel 
to patients. J Am Dent Assoc 1985; 110,634-636. https://doi.org/ 10.1016/S0002-8177(15)30015-5

6. ZADIK Y, CHAPNIK L, GOLDSTEIN L: In-flight barodontalgia: analysis of 29 cases in military aircrew. Aviat Space Environ Med 2007; 78 (6), 593-596.

7. KolLmann W: Incidence and possible causes of dental pain during simulated high altitude flights. J Endod 1993; 19, 3, 154-159. https://doi.org/10.1016/S0099-2399(06)80512-1

8. HolowatyJ RE: Barodontalgia among flyers: a review of seven cases. J Can Dent Assoc 1996; 62 (7), 578-584.

9. ReINKE CH: Barodontalgia - Toothache triggered by hypobaric and hyperbaric conditions https://military-medicine.com/article/ 3102-barodontalgia-toothache-triggered-by-hypobaric-hyperbaric -conditions.html Retr.: 2019.03.13.

10. FeRJENTSIK E, AKer F: Barodontalgia: a system of classification. Mil Med 1982; 147, 4, 299, 303-304. https://doi.org/10.1093/milmed/ 147.4.299

11. ZADIK Y: Barodontalgia. J Endod 2009; 35, 4, 481-485. https:// doi.org/10.1016/j.joen.2008.12.004

12. ZADIK Y: Barodontalgia: what have we learned in the past dec- ade? Oral Surg Oral Med Oral Pathol Oral Radiol Endod 2010; 109 (4) https://doi.org/10.1016/j.tripleo.2009.12.001

13. Schmid M, Schädelin $S$, KüHL $S$, et al: Head and dental injuries or other dental problems in alpine sports Clin Exp Dent Res 2018; 4, 125-131. https://doi.org/10.1002/cre2.121

14. YASA D: The effects of flying on your body explained Escape, 2018. Feb. 2. https://www.escape.com.au/ Retr: 2019.05.15.

15. ZADIK Y: Aviation dentistry: current concepts and practice British Dental Journal 2009; 206, 11-16. https://doi.org/10.1038/sj.bdj. 2008.1121

16. Phelan JR: Otolaringology in aerospace medicine In.: Davis JD, Johnson R, StepaneK J: eds. Fundamentals of Aerospace Medicine, 4h. Ed. 2008, Philadelphia, Wolters Kluwer/Lippincott Williams \& Wilkins

17. Bryan B: Flying after dental implant surgery? What are the rules? https://www.bauersmiles.com/2016/09/flying-after-dental-implantsurgery.html/ Retr: 2019.05.14.

18. KeDJavune U, LegGat PA: Dental Precautions For Travelers $J$ Travel Med 1997; 4, 38-40. https://doi.org/10.1111/j.1708-8305.1997. tb00771.x

\section{Clinical trial}

\section{Felkai P, Felkai T, Rózsa N}

\section{Pretravel advice - dentists' approach}

Taking into consideration two main factors: the general poor condition of dental health of the population and that elderly people are becoming more and more active in traveling one can draw the conclusion that pretravel advice must contain dental issues too. Authors suggests some travel related medical problems such as infection control, a reliable dental service abroad, the proper way of cleaning teeth and prosthesis where safe water isn't available, failures with the dentures and braces.

However the more important issue is the timing of air travel after dental interventions in order to avoid barodontalgia. Unfortunately, the international literature hardly mentions this kind of problem, although it would be useful both for dentists and for the general practitioners and travel medicine professionals. There is no evidence based rules for the optimal duration between the dental intervention and air-travel so authors collect the relevant professionals' opinion. According to their approach the minimum waiting time should be 24 hours after filling and dental extraction, in the case of implantation without complication it is $24-48$ hours, while in case of more difficult interventions connecting to implantation this time can take up to 2 weeks and root canal manipulation requires at least 72 hours but a week proved to be more safe etc.

The determining of optimal time of air travel after dental interventions requires more detailed surveys but hopefully the time-suggestions of this paper is good for a rough estimation. The exact timing should be decided by the treating doctor and it is depended on the patient's condition and the type of the intervention.

Keywords: dentist, travel medicine, pretravel advice, barodontalgia, air travel, dental tourism 